\title{
The Environmental Behavior Research in Pakistan: Why it is Needed? And What Questions it Should Address?
}

Faiz Rasool

\author{
MS leading to PHD candidate, \\ Department of Sociology, \\ University of Karachi, Karachi. \\ Email: faiz7r@gmail.com
}

Doi:10.5901/mjss.2013.v4n6p285

\begin{abstract}
Environmental problems are recognized as one of the major threat for humanity in the twenty-first century. Problems such as climate change and environmental pollution are affecting human health and livelihoods. Pakistan is also confronting several environmental challenges. Social scientists are studying the human dimension of environmental problems. Recently, interest in how everyday behaviors of individuals can cause negative environmental changes and how to encourage individuals to perform environmentally friendly behaviors has increased. The social and psychological determinants of individual environmental behaviors have been widely studied in recent times. The research on environmental behaviors in Pakistan is in its initial phase. The objective of this paper is to discuss the potential role of social sciences in improving the environmental protection by promoting responsible environmental behaviors in Pakistan, and to discuss the need for further researches in future on individual environmental behaviors in Pakistan. Finally attention is drawn to some of the questions that environmental behavior research in Pakistan should address in future studies.
\end{abstract}

Keywords: environmental behavior, Pakistan, environmental problems, Islam, social sciences.

\section{Introduction}

There is little doubt that environmental problems are one of the biggest challenges for humanity in the twenty-first century (Dunlap \& Marshall, 2007). Climate change, scarcity of natural resources, deforestation, loss of biodiversity, overpopulation, and pollution are some of the major environmental problems of the world today (Oskamp, 2000). These environmental problems are affecting the present generation in many ways, and their negative impacts are likely to grow. Millions of people are facing water scarcity, air pollution is one of the major causes of mortality worldwide, floods and droughts may increase as a result of climate change, and people are being forced to migrate because of environmental changes (Moran, 2010; Oskamp, 2000).

Individual and collective human actions are considered chiefly responsible for the dangerous changes occurring in the environment, and some of these changes are "irreversible" (Moran, 2010). Throughout history, humans have evolved new methods to cope with their environmental conditions and have also made changes to their environments (Stern, 2000). Before the industrial era, humans never altered their environment to an extent that the environment could not restore itself to the original state. However, since the start of the industrial era humans have made unprecedented changes in the environment (Bitousek, Mooney, Lubchenco \& Melillo, 1997).

There is little disagreement in the scientific community that the current environmental crisis is a consequence of human activities. Winter and Koger (2004) point out that in the view of many people governments and international institutions will eventually discover ways to overcome the contemporary environmental challenges of climate change and resource scarcity. Also many people are convinced that soon technological developments will find a solution to solve all of humanities current environmental problems (Winter \& Koger, 2004). However, many environmental problems have emerged not because of technological deficiencies but as a result of human activities and needs. Forests are under threat because of demands for wood, biodiversity is increasing because humans are destroying habitats, rivers an seas are polluted because humans are dumping all kinds of waste in them (Stern, 2000; Winter \& Koger, 2004).

Since the second half of the twentieth century, social scientists have become more and more interested in studying human dimension of environmental problems (See Barr, 2007 for an overview of the development of this 
research in North America and England). In the initial phase of this academic development, industrial and transport sectors received much attention. Gradually, the importance of the role of everyday individual behaviors e.g. energy conservation, recycling, water conservation, and buying environmentally friendly products has been realized in protecting or harming the environment. Though the environmental impacts of aggregate individual actions are not equal to the impacts of the industrial and transport sector, but individuals through their actions e.g. Buying recycled paper and decisions e.g. choosing to walk instead of driving can protect the environment. As a consumer, individuals have a power to influence industries to reduce their environmental impacts, and as voters individuals can influence governmental policies about environmental issues.

In Europe and in North America, and more recently in many developing countries hundreds of studies have been conducted on social and psychological determinants of individual actions that are environmentally significant. This developing field of inquiry is often described as environmental behavior research (Stern, 2000).

The objective of this paper is to discuss the need for more research on environmental behaviors in Pakistan.

Pakistan is facing numerous environmental problems (Pakistan Environmental Protection Agency [PEPA], 2005). The research on environmental behavior has sown its seeds in Pakistan. In this paper, it is argued that there is a need for more researches on environmental behaviors in Pakistan. It needs to be established, through qualitative and quantitative research, that what social and psychological factors influence environmental behaviors in Pakistan. This understanding can be used in designing programs and policies that encourage environmental friendly behaviors and promote responsible environmental citizenship in Pakistan (Martinsson \& Lundqvist, 2010).

The rest of this paper is organized as follows. In section two of the paper, some of the major environmental problems of Pakistan and their consequences are reviewed. Section three of the paper, discusses the definition of environmental behavior, theories to explain environmental behavior, and barriers to pro-environmental behaviors. The fourth section discusses the need for conducting environmental behavior researches in Pakistan. In The final section of the paper some of the questions that need to be addressed by future environmental behavior research in Pakistan are discussed.

\section{Environmental problems of Pakistan}

Pakistan is facing many environmental problems. Ambient air quality in urban areas, increasing population, soil erosion, water scarcity, marine pollution and inadequate waste management are some of its environmental problems (Asian Development bank $[A D B], 2008 ;$ PEPA, 2005). The environmental problems of Pakistan are broadly related to management of scarce natural resources, waste management, environmental pollution, vulnerability to natural disasters and climate change (ADB, 2008; PEPA, 2005). ADB (2008) argues that Pakistan achieves economic growth at the cost of natural resources, upon which the economy relies. Annually Pakistan is losing Rs. 365 billion due to environmental degradation, and the resulting burden of disease (World Bank [WB], 2006).

Pakistan is among those countries that are likely to be severely affected by climate change. Agriculture, energy, biodiversity, economy and health are some of the sectors that are expected to be most influenced by it. The risks of natural disasters such as flooding and cyclones in Pakistan have increased as a consequence of climate change (ADB, 2008; PEPA, 2005). Scarcity of water, variations in rainfalls and heat stress are some of the predicted impacts of climate change on Agriculture. Already, Pakistan is a water-stress country. Climate change can cause the melting of glaciers. These glaciers are a source of water for rivers in the country. The decline in agricultural production and water scarcity can spread hunger in Pakistan, and can cause food shortage. Climate change is also responsible for increasing the likelihood of natural disasters and stream weather events in Pakistan. Floods are likely to increase and droughts are likely to ensue. Rise of 1.1 Millimeters each year have been recorded in sea level. Its impacts are likely to be erosion, inundation and displacement of wetlands (PEPA, 2005).

The linkage between environmental degradation and poverty is also present in Pakistan. About $70 \%$ of population in Pakistan is rural, out of which $34 \%$ is poor. Poor are most affected by the decline in the environmental quality both in urban and rural areas. The poor from rural areas do not have any formal source of income, and they are dependent on agriculture and natural resources for their livelihoods. Livestock, fishing, and miner forestry products are there source of income. Rangelands are losing their productivity Due to environmental decay, and Poor rely on them to graze livestock (ADB, 2008). This is increasing the burdens of environmental degradation on their livelihoods. The plight of poor makes them most vulnerable to the health risks linked with environmental pollution. They are more likely to drink polluted water, and breathe in polluted air. As a result they suffer from waterborne diseases and respiratory illnesses. They also lack the economic resources needed for seeking treatment (WB, 2006). 
The loss of biodiversity and deforestation are pressing environmental issues of Pakistan (ADB, 2008; PEPA, 2005). Biodiversity is important for continued existence of food chain, and it is a source of livelihoods for poor communities. It is also important for the health of ecosystems. In Pakistan, many species are lost and several others are internationally threatened. Few natural habitats are intact, while others have been lost as a result of human activities (ADB, 2008). During last 100 years, Pakistan has lost much variety of animal and plant life. Some of the factors that can explain the loss of biodiversity are the high growth rate of population, hunting of animals, deforestation, pollution and loss of habitats.

Pakistan is ranked second as the country with the highest rate of deforestation. Annually 0.2 to 0.5 percent forests are lost in Pakistan. The fact that it is a forest-poor country makes this statistic more concerning (PEPA, 2005). Deforestation is a result of the demand for wood by the industrial sector. Wood is also widely used as a fuel across the country. Forests make sure that ecosystems maintain their health, and they protect biodiversity.

Forest can be a source of generating revenue through tourism. The mangroves forests that are situated along the coast of Sindh are lost at a rate of 4,900 annually. These forests play vital economic and ecological roles. They prevent the port from accumulation of silt, provide breeding ground for fish larvae and are a sanctuary for birds.

The outdoor air quality in urban areas of Pakistan is another serious environmental challenge. This ambient quality of air is a result of emission of pollutants from Power plants, industries and vehicles driven by fossil fuels. The levels of air pollution in major Pakistani cities are much higher than the levels recommended by World Health Organization (PEPA, 2005). According to Asian Development Bank (2008), in the year 2001 the concentration of suspended particulate matter in Lahore, Rawalpindi, and Islamabad were four to seven times higher than the recommended levels by World Health Organization. Even higher levels of fine particulate matter were measured in Gujranwala and Faisalabad in the year 2003 and in Quetta in 2006 (ADB, 2008). As the number of vehicles on the roads in Pakistan is increasing the problem of air pollution is likely to further aggravate. Outdoor air pollution is not the only serious threat. Indoor air pollution is an equally significant problem for human health. Still many households use biomass fuel for cooking and heating purposes in Pakistan. Burning biomass fuels indoors can cause indoor air pollution. According to World Bank (2006) indoor and outdoor pollution is a major cause of mortality in Pakistan.

Inadequate management of solid and hazardous waste is also an environmental problem of Pakistan. Roughly 48,000 tons of solid waste is generated every day (ADB, 2008; PEPA, 2005). Generally waste is not collected and disposed environmentally in the country. As a result conservable resources are wasted; improper handling of waste results in adverse health effects and the environment is polluted. It is common to throw Waste in streets and on roadsides. In absence of proper waste collecting system, at times the waste originating from hospitals gets mixed with the other forms of solid waste. The waste is dump on low-lying lands, or it is burned. The industrial sector is responsible for discharging pollutants like heavy metals and chemicals into land and water bodies. Some of the discharged pollutants contaminate precious natural resources such as rivers and fresh ground water. Untreated waste lying in open space is a source of many health issues.

Risk of water scarcity is another concerning problem for Pakistan. According to PEPA (2005), it is likely that per capita availability of water will drop below one thousand cubic meters in coming years (see table 1). This makes Pakistan a water-stress country, and increases the significance of developing a water management system and promoting water conservation.

Table 1. Per capita availability of water in Pakistan.

\begin{tabular}{|c|c|c|}
\hline YYear & Population (in millions) & Per capita availability of water (meter cube) \\
\hline 11951 & 34 & 5300 \\
\hline 11961 & 46 & 3950 \\
\hline 11971 & 65 & 2700 \\
\hline 11981 & 84 & 2100 \\
\hline 11991 & 115 & 1600 \\
\hline 22001 & 148 & 1200 \\
\hline 22013 & 207 & 850 \\
\hline 22025 & 267 & 659 \\
\hline
\end{tabular}

Source: The state of environment report (PEPA, 2005, P. 40) 


\section{Environmental behavior: its definition and models to understand it}

Environmental behavior is a generic term for all types of individual or collective human behaviors that make a direct or indirect impact on the environment. In few contexts environmental behavior has been used to refer to the impacts of biophysical environment on human behavior e.g. impact of the surrounding architecture on human actions. However, in social science's disciplines, environmental behavior refers to the former meanings of the term.

Stern (2000) defines environmentally significant behavior as "behaviors that changes the availability of materials or energy from the environment or alters the structure and dynamics of ecosystems or biosphere" (Stern, 2000, P. 408). Environmental behaviors do not refer to one uniform category of behaviors. There are different types of environmental behaviors. Following Stern (2000) environmental behaviors can be divided in the following distinct categories: Environmental activism e.g. taking part in demonstrations and environmental organizations, non-activist behaviors in the public sphere e.g. stating approval of environmental regulations, private-sphere environmental behaviors e.g. everyday household behaviors that have environmental implications such as recycling, water conservation, reducing waste generation and conserving energy (Bartiaux, 2008; Corral-Verdugo, Bechtel, \& Fraijo-Sing, 2003; Tonglet, Phillips, \& Bates, 2004), and green consumerism e.g. buying products that are environmentally friendly (Stern, 2000, pp. 408409).

The interest in human induced environmental changes grew after the publication of Rachel Carson's widely cited book Silent Spring (Carson, 1962). In her book, Carson highlighted the impacts of pesticide use on birds. The publication of Silent Spring helped in spreading the realization that humans need to protect and preserve the environment. In the decades of 1960s and 1970s industrial and transport sectors were identified as sectors where changes were needed to reduce the environmental degradation. More recently, the significance of everyday individual environmental behaviors has also been realized (Benders, Kook, Moll, \& Wiersma, 2006).

Hardon (1968) in his famous essay "tragedy of the commons" demonstrates how considering the role of one individual in protecting the environment insignificant can be incorrect. To support his argument, Hardon uses an example of a pasture which is a source of food for herder's animals. If there are four herders, each owning ten Goats and the pasture is providing for all forty Goats, this means that herders are living in harmony with their environment. Now, it is beneficial for all herders to consider increasing the size of their herds. If one of these herders increases his Goats from ten to fifteen, and others follow him, this would mean that now the pasture has to provide food for Sixty Goats which is beyond its capacity. In this same way, each individual considers environmental impacts of his actions negligible but when thousands and thousands of people start to live with this attitude, the risk of environmental catastrophe increases.

\subsection{Models to explain environmental behaviors.}

Researchers have developed different theoretical approaches to explain and analyze environmental behaviors. Here, three theories that have been widely used by researchers are reviewed.

\subsubsection{The norm activation model:}

The norm activation model (NAM); Schwartz (1977), has been used in several studies on environmental behaviors (Harland, Staats, \& Wilke, 2007; Milfont, Sibley, \& Duckit, 2010). NAM was developed to explain altruistic behaviors. Since environmental behaviors can be categorized as one type of altruistic behaviors; it has been used by researchers in studying environmental behaviors (Abrahamse, Steg, Vlek, \& Rothengatter, 2005). NAM Posits that behavior is influenced by three variables. The first of these variables is personal norm which refers to the moral obligation of whether to perform or not to perform a given behavior (De Groot \& Steg, 2009), for example, whether to make a conscious effort to conserve water so others may not face water scarcity. The second variable is awareness of consequences which refers to the awareness of individual about the negative impacts of his actions on the things that he values, for example, Knowledge of individual that if he is not careful in use of water, its scarcity may be faced by other people. The third variable, ascription of responsibility refers to feeling responsible for the negative impacts of not taking an action, for example feeling responsible for the water scarcity faced by others. NAM can prove useful in explaining pro-environmental behaviors which are not very difficult to perform. The NAM variables have been used by Stern and colleagues to develop values-beliefs-norms theory. 


\subsubsection{Values-Beliefs-Norms Theory:}

Values-Beliefs-Norms (VBN) theory (Stern, 2000; Stern et al., 1999) connects individual's beliefs about the humanenvironment relationship and individual value orientation with the NAM. A popular measure to measure individual belief about the relation of human-environment is the new ecological paradigm scale (NEP) (Dunlap, Van Liere, Mertig, \& Jones, 2000). In VBN framework, three types of values, namely, egoistic, altruistic and biospheric values are identified (Abrahamse et al., 2005). Individual who have egoistic values are mainly concern about their own wellbeing and undertake pro-environmental actions when it is in their interest. Individuals who have an altruistic value orientation are concerned about the wellbeing of other humans. They are likely to perform pro-environmental actions not only for themselves but for the benefit of others as well. Individuals who have a biospheric value orientation are not just worried about their own and other human's wellbeing, they are also concerned for plants and animals. Such individuals perform pro-environmental behaviors to benefit all humans as well as plants and animals. Like the NAM, VBN theory proposes that personal norm is the ultimate predictor of behavior. The personal norm depends on awareness of consequences and ascription of responsibility. VBN theory generalizes the NAM by postulating that awareness of consequences and ascription of responsibility are influenced by beliefs of an individual about the relationship of humans with the environment and individual's value orientation (Stern, 2000).

\subsubsection{Theory of planned behavior:}

Another widely used theory in studies of environmental behavior is theory of planned behavior (TPB) presented by Ajzen (1991). TPB has been used to study different types of environmental behaviors (e.g. Clark \& Finley, 2007; Trumbo \&O'keefe, 2001). It proposes that behavioral intention is the most important predictor of behavior. Intention refers to the willingness of an individual of performing or not performing the behavior in question, e.g. the degree of willingness to conserve electricity. Behavioral intention is influenced by three factors (Bamberg \& Schmidt, 2003). The first factor is Attitude towards the behavior. This attitude is based on the rational evaluation of the consequences of the behavior. The second factor is subjective norms, which refers to perceived social pressure to perform a behavior. The Third factor is perceived behavioral control, which refers to the degree of control individual feels that he has over performing a behavior. According to TPB, positive attitude towards the behavior, existence of subjective norms and feeling of control to perform a behavior leads to the behavioral intention which finally results in behavior being performed. Likewise, negative attitude towards the behavior and a sense of low control to perform a behavior may result in behavioral intention not been developed and consequently behavior being not performed.

\subsection{Methodology of studying environmental behaviors}

Qualitative and quantitative methods have both been used to study environmental behaviors (Barr, 2007). Self-report method where individuals are requested to indicate the frequency of a given action is the most common technique. Few researchers have also conducted observational studies of environmental behaviors like water conservation (Corralverdugo et al., 2003). Use of focus groups discussions has also been a common data gathering strategy. The social and psychological determinants of environmental behaviors have been measured using quantitative, likert type scales. Some of the determinants that have been measured using quantitative techniques include environmental concern, environmental attitudes, environmental values, and environmental awareness (De Groot \& Steg, 2008; Gilg \& Barr, 2006; Milfont, Duckit, \& Cameron, 2006). Two of the most widely used scales are the NEP scale (Dunlap et al., 2000), and the Schwartz's value scale (Stern, 2000). Schwartz's value scale is an attempt to see whether there is some universality in the type of values people hold across cultures. Environmental behavior researchers have mainly used Schwartz value scale to explore that is an individual more close to egoistic values or more close to altruistic values.

\subsection{Barriers to perform environmental behaviors}

Blake (1999) has classified barriers to pro-environmental behaviors in three categories. Individuality, responsibility and practicality are these categories. In individuality, Blake includes those barriers which are connected with the personality of the individuals. He maintains that showing low or no concern about the environmental problems result in failure to take actions that are pro-environmental in nature. For example: reducing use of a car and recycling are barriers that Blake places in individuality. Feelings that others are responsible, and that actions will not help a lot are barriers to pro- 
environmental behavior that Blake calls responsibility. Practicality refers to social and institutional factors that prevent the individual to perform a pro-environmental behavior. Examples of the barriers in this category are lack of time and lack of money (Blake, 1999; Kollmuss \& Agyeman, 2002).

\section{The need for environmental behavior research in Pakistan}

The existing state of Pakistan's environment was reviewed in section two of this paper. In this section it is discussed that there is a need for a more prominent role of social scientists to research, and theorize about environmental behavior in Pakistan. The awareness of the environmental impacts of everyday actions is very low in Pakistan. Likewise there is little appreciation, at the individual level, of the environmental challenges that are currently faced by Pakistan, and the expected challenges that will arise in future. The national environmental policy of Pakistan acknowledges the significance of increasing public awareness about the environmental issues.

For a long time the human dimension of environmental problems did not receive deserving attention of social scientists in Pakistan. Recently this has started to change. Studies conducted on green consumerism by Pakistani researchers have started to appear in international journals in last three to four years (e.g. Ahmad, Ali, Florentina, \& Stancu, 2012; Ahmad, Shah, \& Ahmad, 2010; Ali, Khan, Ahmed, Shahzad, 2011; Shaikh \& Rahman, 2011; Subhani, Hasan, Osman, Rudhani, 2012). Subhani Et al. (2012) found that social influence, environmental concern, and perceive seriousness of the problem influence brand preference of consumers. Subhani et al. also found that environmental concern and social influence affect females in selecting products that have been marketed as green, whereas males are affected by perception about the environmental friendliness of a brand and environmental concern. The research on green consumerism and on all other forms of environmental behavior needs to grow in Pakistan. In proceeding paragraphs a case for more and comprehensive research on environmental behavior is made.

Pakistan is among the largest countries of the world in terms of population. In last fifteen years Pakistani society has been exposed to two major agents of social change, namely, computer and cable television. This has resulted in impacts of globalization intruding in every aspect of Pakistani society. One noticeable social change in urban areas of Pakistan is increased consumption of fast-food. Packaging of home delivered fast-food items have increased and changed the nature of everyday waste generation. The use of electronic items such as cell phones, computers, printers, and scanners has added electronic waste into the composition of everyday waste as well.

It was discussed earlier that Pakistan faces a serious risk of water scarcity. Despite this, water flowing out of overflowed water tanks is a common sight in the country. Few people take water preservation into account when watering gardens, washing cars, and houses.

$\mathrm{CO} 2$ emission of Pakistan is also increasing. Recently released data shows that Pakistan is the second largest $\mathrm{CO} 2$ emitter in south Asia. Pakistan's CO2 emissions have increased in last five years. Power generation plants and transport sector share a large proportion of this $\mathrm{CO} 2$ emission, but by making small changes in how energy is consumed individuals can play a significant role in reducing $\mathrm{CO} 2$ emissions. To a layman in Pakistan, the linkage between everyday energy usage and $\mathrm{CO} 2$ emissions is not apparent even though fossil fuels are one of the major sources of electricity production in the country. So when individuals conserve energy in their houses, they can help the environment by reducing $\mathrm{CO} 2$ emissions.

Table 2. Annual CO2 emissions of South Asian countries.

\begin{tabular}{|l|l|l|l|l|l|}
\hline Year & $\mathbf{2 0 0 5}$ & $\mathbf{2 0 0 6}$ & $\mathbf{2 0 0 7}$ & $\mathbf{2 0 0 8}$ & $\mathbf{2 0 0 9}$ \\
\hline Afghanistan. & 0.6525 & 0.64431 & 0.66175 & 0.67464 & 0.68931 \\
\hline Bangladesh. & 13.09298 & 13.86875 & 13.86461 & 14.2072 & 14.6655 \\
\hline Bhutan. & 0.16196 & 0.16041 & 0.21811 & 0.18306 & 0.14082 \\
\hline India. & 314.15478 & 349.20805 & 353.56208 & 372.40259 & 392.6007 \\
\hline Maldives. & 0.602 & 0.8265 & 0.93243 & 0.88832 & 0.91895 \\
\hline Nepal. & 2.27167 & 2.19728 & 2.16124 & 2.23882 & 2.30352 \\
\hline Pakistan. & 51.79302 & 55.18943 & 59.12057 & 59.69908 & 61.40035 \\
\hline Sri Lanka. & 61.40035 & 12.5526 & 12.87076 & 12.24569 & 12.54077 \\
\hline
\end{tabular}

Source: Energy information administration (2010). Table retrieved from http://www.eia.gov/cfapps/ipdbproject/IED Index3.cfm?tid=5\&pid=5\&aid=8 
Note: The data in the above table of $\mathrm{CO} 2$ emissions is of emissions due to fossil fuel burning. These statistics do not include the $\mathrm{CO} 2$ emissions of cement sector.

\section{Questions for future environmental behavior research in Pakistan}

The future research on environmental behaviors in Pakistan has to address the following key questions. First it has to examine the nature of the relationship of different social, psychological and demographic variables with environmental behaviors of individuals in Pakistan. Though researchers have identified several factors that influence environmental behaviors (see Bamberg \& Möser, 2007) for a meta- analysis of social and psychological determinants of environmental behaviors. However, many of these studies have been conducted in Western developed countries. Therefore, environmental behavior research in Pakistan has to consider the relevancy of scales developed in Western countries to measure variables such as environmental values, attitude and worldviews for Pakistani context. The NEP scale (Dunlap et al., 2000), environmental concern scale (Schultz et al., 2005), environmental values scale (De Groot \& Steg, 2008), are examples of few scales developed in Western countries and that have been widely used by researchers of environmental behaviors. Since the research on environmental behavior is just emerging in Pakistan, empirical evidence supporting or refuting the reliability and validity of measures like these for research in Pakistan is lacking. One way to overcome this problem can be to conduct comparative researches. In these researches, researchers in Pakistan can develop their own scales, to measure constructs like environmental attitudes and concern which they feel are more sensitized to the Pakistani society, and use an available instrument in the literature. By comparing the reliability of the newly developed measure and of the measure taken from the literature, the question of relevancy and applicability of research measures used outside of Pakistan for Pakistani context is likely to be answered.

Future researches should also consider examining the role of Islam in influencing, and motivating friendly environmental behaviors. Fazlun Khalid, a leading Muslim environmental activist and a prominent writer on environmental problems has tried to use Islamic teachings to encourage pro-environmental behaviors among Muslims in United Kingdom. The potential of making individuals realize the Islamic ethics about environmental resources in order to promote environmentally friendly actions is largely untapped in Pakistan (Khalid, 2010).

Table 3 presents few questions that future research on environmental behaviors in Pakistan should consider and a few suggestions of how to answer these questions. These questions and suggestions should not be construed as not requiring any modifications in future. As research literature develops some of these questions may be answered and new questions arise. Also, researchers may wish to explore answers of the questions in table 3 as per their own choice of research approach.

Table 3 Questions for future environmental behavior research in Pakistan and how to answer them.

\begin{tabular}{|l|l|}
\hline \multicolumn{1}{|c|}{ Questions } & \multicolumn{1}{|c|}{ A possible way to answer. } \\
\hline $\begin{array}{l}\text { Do individuals in Pakistan see a connection } \\
\text { between their everyday behavior and the } \\
\text { environmental problems? }\end{array}$ & $\begin{array}{l}\text { Focus groups, in-depth interviews, followed by } \\
\text { questionnaire based surveys. }\end{array}$ \\
\hline $\begin{array}{l}\text { Which theoretical approach is most appropriate to } \\
\text { explain environmental behaviors in Pakistan? }\end{array}$ & $\begin{array}{l}\text { Surveys using scales to measure constructs of different } \\
\text { theories and contrasting their ability to predict environmental } \\
\text { behaviors. }\end{array}$ \\
\hline $\begin{array}{l}\text { How to develop reliable and valid scales to } \\
\text { measure psychological predictors, such as as } \\
\text { attitudes and values, of environmental behaviors? }\end{array}$ & $\begin{array}{l}\text { Scale development giving due consideration to the local } \\
\text { context and using an existing scale in the literature and } \\
\text { comparing the reliability of both scales. }\end{array}$ \\
\hline $\begin{array}{l}\text { What are the social, psychological, and institutional } \\
\text { barriers for individuals to undertake } \\
\text { environmentally friendly behaviors? }\end{array}$ & Ethnographies focus groups and surveys. \\
\hline $\begin{array}{l}\text { How to design campaigns to foster positive } \\
\text { environmental behaviors in Pakistan? }\end{array}$ & $\begin{array}{l}\text { Keeping in view the findings of research, and constant } \\
\text { monitoring of the results of the campaign in the initial stage } \\
\text { so any required changes can be made in time. }\end{array}$ \\
\hline $\begin{array}{l}\text { How to spread awareness of Islamic environmental } \\
\text { ethics in Pakistani Society? }\end{array}$ & $\begin{array}{l}\text { Through Mosque Imams, Islamic scholars, media, and } \\
\text { schools, colleges and universities. }\end{array}$ \\
\hline
\end{tabular}




\subsection{Social sciences and national environmental policy of Pakistan}

The goals and objectives of national environmental policy of Pakistan (ministry of environment, 2005) are unlikely to be achieved without the due role of social scientists. The goal of the policy is "to protect, conserve and restore Pakistan's environment in order to improve the quality of life of the citizens through sustainable development."

Objective 1 of the national environmental policy is "Conservation, restoration and efficient management of environmental resources." Objective 5 of the policy is "Creation of a demand for environment through mass awareness and community mobilization."

Policymakers can use Economic or social-psychological approaches to encourage individual pro-environmental actions In pakistan. Following the economic approach environmental penalties can be introduced. Households, for example, can be charged per kilogram of the waste they are generating by local waste collection authorities. In the social and psychological approach social marketing techniques can be used to make people take environmentally friendly actions. Since poverty is a major problem of Pakistan, and generally people are not use to pay heavily for services like water and waste management, the social- psychological approach is likely to be more appropriate. This situation further provides support to the argument that in future social scientists have to, and can play a vital role in finding solutions to Pakistan's environmental challenges by developing stratigies to foster pro-environmental behaviors at the individual, household, organizational, and societal level.

\section{Acknowledgements:}

An earlier version of this paper was presented at the 18th National Research Conference, Shaheed Zulfikar Ali Bhutto Institute of Science and Technology (SZABIST), Karachi. The discussion on environmental problems of Pakistan in this paper, draw on a section of the author's dissertation for Masters in Sociology.

The Author would like to thank Dr. Bruce Wearne for his helpful comments on earlier drafts of this paper, and Ms. Humaira Siddiqui for help in proofreading the manuscript."

\section{References}

Abrahamse, W., Steg, L., Vlek, C., \& Rothengatter, T. (2005). A review of intervention studies aimed at household energy conservation. Journal of Environmental Psychology, 25, 273-291.

Ahmad, J., Ali, I., Florentina, G., \& Stanncu, A. (2012). Studying consumers' ecological consciousness - a comparative analysis of Romania, Malaysia and Pakistan. Amfiteatru Economic, 14(31), 84-98.

Ahmad, H., Shah, I., \& Ahmad, K. (2010). Factors in environmental advertising influencing consumer's purchase intention. European Journal of Scientific Research, 48(2), 217-226.

Ajzen, I. (1991). The theory of planned behavior. Organizational Behavior and Human Decision Processes, 50, $179-211$.

Ali, A., Khan, A., \& Ahmed, I. (2011). Determinants of Pakistani Consumers' Green Purchase Behavior: Some Insights from a Developing Country. International Journal of Business and Social Science, 2(3), 217-226.

Asian development Bank (2008). Pakistan: Country environmental analysis. Retrieve from http://www.adb.org/environment/cea.asp

Bamberg, S., \& Schmidt, P. (2003). Incentives, Morality, or Habit? Predicting students' car use for university routes with the models of Ajzen, Schwartz, and Triandis. Environment and Behavior, 35(2), 264-285.

Bamberg, S., \& Möser, G. (2007). Twenty years after Hines, Hungerford, and Tomera: A new meta-analysis of psycho-social determinants of pro-environmental behavior. Journal of Environmental Psychology, 27, 14-25.

Bartiaux, F. (2008). Does environmental information overcome practice compartmentalization and change consumers' behaviours. Journal of Cleaner Production, 16(11), 1170-1180.

Barr, S. (2007). Environment and Society. London: AsheGate

Benders, R. M. J., Kok, R., Moll, H., Wiersma, G. \& Noorman, K. (2006). New approaches for household energy conservation- In search of personal household energy budgets and energy reduction options. Energy Policy, 34, 3612-3622.

Bitousek, P., Mooney, H., Lubchenco, J., \& Melillo, J. (1997). Human domination of Earth's ecosystems. Science, 277, 494-498.

Blake, J. (1999). Overcoming the value-action gap in environmental policy: Tensions between national policy and local experience. Local Environment, 4(3), 257-278.

Carson, R. (1962). Silent Spring. Boston: Mifflin.

Clark, W., \& Finley, J. (2007). Determinants of Water Conservation Intention in Blagoevgrad, Bulgaria. Society and Natural Resources, 20(7), 613-627.

Corral-Verdugo, V., Bechtel, R. B. \& Blanca, Fraijo-Sing. (2003). Environmental beliefs and water conservation: An empirical study. Journal of Environmental Psychology, 23, 247-257. 
De Groot, J., \& Steg, L. (2008). Value orientations to explain beliefs related to environmental significant behavior: How to measure egoistic, altruistic, and biospheric value orientations. Environment and Behavior, 40(3), 330-355.

De Groot, J., \& Steg, L. (2009). Morality and prosocial behavior: The role of awareness, responsibility, and norms in the norm activation model. Journal of Social Psychology, 149(4), 425-449.

Dunlap, R. E., Van Liere, K. D., Mertig, A. G., \& Jones, R. E. ( 2000). Measuring endorsement of the new environmental paradigm: A revised NEP Scale. Journal of Social Issues, 56(3), 425-442.

Dunlap, R., \& Marshall, B. (2007). Environmental Sociology. In Clifton D. Bryant \& Dennis L. Peck (eds.), 21st century Sociology: A reference handbook (pp. 329-338). New Delhi: Sage

Energy information administration (2010). International energy statistics. Retrieved from http://www.eia.gov/cfapps /ipdbproject/IEDIndex3.cfm?tid=5\&pid=5\&aid=8

Gilg, A., \& Barr, S. W. (2006). Behavioural attitudes towards water saving? Evidence from a study of environmental actions. Ecological Economics, 57, 400-414.

Hardin, G. (1968). Tragedy of the commons' Science, 162, 1243-1248.

Harland, P., Staats, H., \& Wilkeb, H. (2007). Situational and personality factors as direct or personal norm mediated predictors of proenvironmental behavior: Questions derived from norm-activation theory. Basic and Applied Psychology, 29(4), 323-334.

Kaiser, F., Ranney, M., Hartig, T., \& Bowler, P. (1999). Ecological behavior, environmental attitude, and feelings of responsibility for the environment. European Psychologists, 4(2), 59-74.

Khalid, F. (2010). Islam and the environment - ethic and practice an assessment. Religion compass, 4(11), 707-716.

Kollmuss, A. \& Ajyeman, J. (2002). Mind the Gap: why do people act environmentally and what are the barriers to pro-environmental behavior? Environmental education research, 8(3), 239-260.

Martinsson, J., \& Lundqvist, L. (2010). Ecological citizenship: coming out 'clean' without turning 'green'? Environmental Politics, 19(4), 518-537.

Milfont, T., Duckitt, J. \& Cameron, L. (2006). A CROSS- CULTURAL STUDY Of ENVIRONMENTAL MOTIVE concerns AND THEIR implications for proenvironmental BEHAVIOR. Environment and Behavior, 38(6), 745-767.

Milfont, T., Sibley, S., \& Duckit, J. (2010). Testing the moderating role of the components of norm activation on the relationship between values and environmental behaviour. Journal of Cross Cultural Psychology, 41(1), 124-131.

Moran, E. (2010). Environmental social science: Human-environment interactions and sustainability. Hoboken,NJ: John Wiley and Sons.

Oskamp, S. (2000). Psychological contributions to achieving an ecologicaly sustainable future for humanity. Journal of Social Issues, 56(3), 373-390.

Pakistan environmental protection agency (2005). State of the environment report (draft). Retrieved from http://www.epa.gov.pk /publications.

Shaikh, A., \& Rahman, M. (2011). Consumers perception of green products: A survey of Karachi. Journal of independent Studies and Research - Management and Social Sciences and Economics, 9(2), 15-28.

Schultz, P. W., Gouveia, V., Cameron, L., Tankha, G., Schmuck, P. \& Franek, F. (2005). Values and their relationship to environmental concern and conservation behavior. Journal of Cross- Cultural Psychology, 36(4), 457-475.

Schwartz, S. H. (1977). Normative influences on altruism. In L. Berkowitz (Ed.), Advances in experimental social psychology, (Vol. 10, pp. 221-279). New York: Academic press.

Stern, P. (2000). Towards a coherent theory of environmentally significant behavior. Journal of Social Issues, 56(3), 407-424.

Stern, P., Dietz, T., Abel, T., Guagnano, G., \& Kalof, L. (1999). A values-belief-norm theory of support for social movements: The case of environmentalism. Humann Ecology Review, 6(2), 81-97.

Subhani, M., Hasan, S., Osman, A., \& Rudhani, S. (2012). The crux of green marketing: An empirical effusive study. European Journal of Social Sciences, 27(3), 425-435.

Tonglet, M., Phillips, P., \& Bates, M. (2004). Determining the drivers for householder pro-environmental behaviour: Waste minimisation compared to recycling. Resources and Conservation, 42, 27-48.

Trumbo, C., \& O'keef, G. (2001). Intention to Conserve Water: Environmental Values, Planned Behavior, and Information AComparison of Three Communities. Society and natural Resources, 14(10), 889-899.

Winter, D., \& Koger, S. (2004). The Psychology of environmental problems (2nd ed.). Mahwah, NJ: Lawrence Erlbaum.

World Bank (2006). Pakistan strategic environmental country assessment. Retrieved from http://go.worldbank.org/VHYXZCYIZO 
